\title{
Tragedy in Antiphon 1, Against the Stepmother
}

It is a privilege to contribute to a volume in honour of Georgia Xanthankis-Karamanos, whose own contributions to the study of Greek drama, especially tragedy, have been so extensive and influential, as also has been her work on rhetoric and the relationship between tragedy and rhetoric. ${ }^{1}$ That relationship has recently been explored again by David Sansone, in a controversial book, Greek Drama and the Invention of Rhetoric, ${ }^{2}$ which has received mixed reviews. ${ }^{3} \mathrm{My}$ purpose here is not to consider the merits or otherwise of Sansone's argument that 'the development of rhetoric was directly inspired by the creation of the new, even revolutionary, genre of tragic drama', ${ }^{4}$ as opposed to the more traditional view that rhetoric influenced tragedy, ${ }^{5}$ but rather to take another look at the undoubtedly tragic elements in what has claims to being the earliest surviving speech in the corpus of Attic oratory, Antiphon 1, Against the Stepmother. ${ }^{6}$ Any attempt to link these directly to recent tragic performances is, to my mind, a vain one, simply because we do not know the dates of many of the plays or indeed of the speech itself. ${ }^{7}$ Rather, in my opinion these elements, combined with other stylistic usages, should be taken first and foremost as indicators of Antiphon's fine oratorical technique.

In Against the Stepmother Antiphon's unnamed client prosecutes his stepmother for the killing of his father. The father was entertained to dinner in Pi-

1 See her early article 1979, 66-76.

2 Sansone 2012.

3 'It is, indeed, one of those books that every reader is happy to have read even though she doubts that it will fully convince anyone': Scodel 2013. See also Lloyd 2013, 457-459; Stewart 2014, 26-28.

4 Sansone 2012, 4.

5 See, for example, Lloyd 1992.

6 For texts, translations, discussions of and commentaries on the speech see Blass / Thalheim 1914; Gernet 1923; Wijnberg 1938; Maidment 1941; Barigazzi 1955; Due 1980, 16-28; Gagarin 1997 and 2002; Gagarin / MacDowell 1998.

7 The dating of the speech is a matter of controversy. Older scholarship, such as Blass 1887, vol. 1, 193; Jebb 1893, vol. 1, 67; and Maidment 1941, 12, would see speech 1 as being a product of Antiphon's earlier development. This view was challenged by Dover 1950, 44-60, who suggests a date between 418/17 and 416/15; and his sequence for the surviving court speeches of 6, 1, 5 is followed by Gagarin 2002, 139. I would still myself prefer a much earlier date, perhaps as far back as the 430s. See Edwards 2000, 236. 
raeus by his friend Philoneus, whose mistress (or $\pi \alpha \lambda \lambda \alpha \kappa \eta$ ) served them wine poisoned with what she believed to be a love potion. Philoneus, receiving a larger draught, died instantly and his friend twenty days later. The mistress was a slave, and so was tortured and executed by relatives of Philoneus. Some years later, on reaching maturity, one of the friend's sons, in accordance with his father's deathbed injunction, prosecuted his stepmother, whose defence was conducted by one of her own sons, the half-brothers of the plaintiff.

With no substantial evidence to rely on, Antiphon constructs for his client a vivid and largely imaginary narrative of these events. Its dramatic tenor was noted many years ago in the Budé edition of Louis Gernet. Commenting on the words which introduce the narrative, Gernet writes:

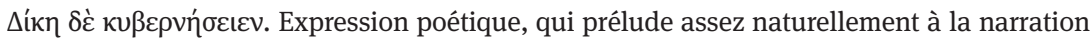

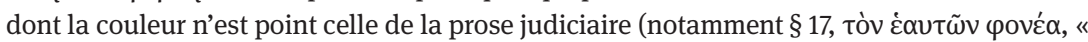
leur meurtrier », en parlant de la coupe empoisonnée; cf. Soph., Ajax, 815 et 1026). Dans la seconde partie surtout - dans la scène du meurtre - ce récit fait penser à celui d'un messager de tragédie; l'auteur y met visiblement quelque complaisance. ${ }^{8}$

Similarly, Adelmo Barigazzi comments:

L'espressione è senz'altro poetica, ma non è il caso di pensare alla chiusa d'un esametro desunta da qualche poeta. Essa appartiene al tono elevato e poetico che charatterizza la narrazione. ${ }^{9}$

On the narrative itself Bodil Due remarks:

This narrative is the broadest and most vivid in the extant speeches of Antiphon ... The litigant obviously strives to create an atmosphere filled with terror and vague presentiments, which is strongly reminiscent of tragedy, especially, as observed by Gernet, of the messenger-speeches. ${ }^{10}$

Finally, Michael Gagarin notes, also with reference to Gernet, that 'A. here produces a vivid account which has been likened to a messenger speech in tragedy'. ${ }^{11}$

There are a number of features of the narrative, and other parts of the speech, that support this consensus opinion. These include:

8 Gernet 1923, 42 n. 1. For the personification Wijnberg 1938, 93, compares Hes. Theogony 902; Soph. OT 274.

9 Barigazzi 1955, 87.

10 Due 1980, 20.

11 Gagarin 1997, 114. 


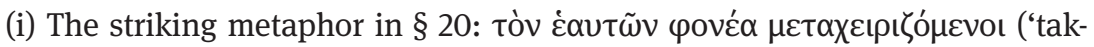
ing hold of their own killer'). Parallels for this, as Gernet noted, are Soph. Ajax

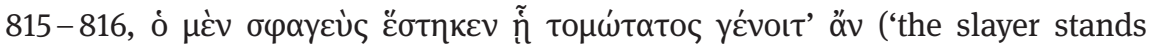

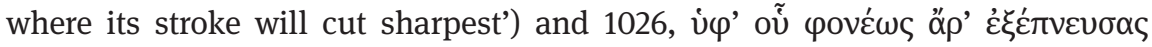
('your killer that took your final breath'), and Due adds Eur. IT 586, oủxì тทेv

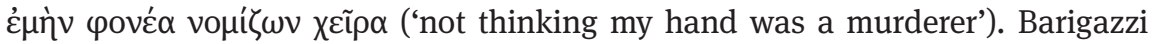
comments 'tutta la frase ha colorito poetico, è piena di solennità e gravità trag-

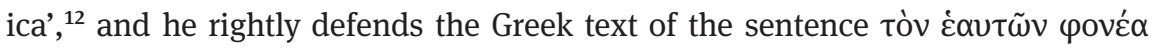

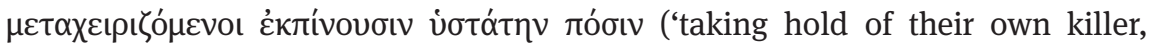

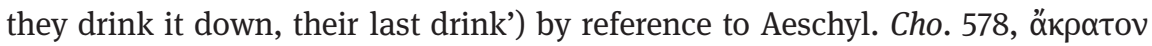

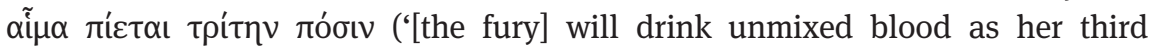
drink'). I note also a fragment of Euripides (912.7 N), which contains the verb

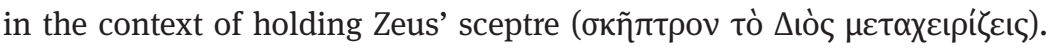

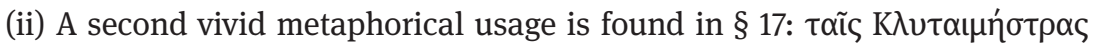

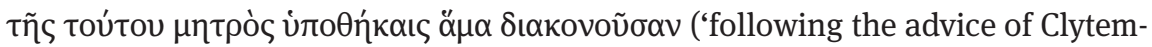
nestra, this man's mother'). ${ }^{13}$ Barigazzi notes that Antiphon would have been about 20 years old when Aeschylus' Oresteia was performed in $458,{ }^{14}$ and Gagarin comments 'the name adds to the tragic tone of the narrative, in which several passages seem intended to recall the Oresteia'. ${ }^{15}$ This is fine, but there were, of course, other versions of the myth, in tragedy and other poetry (starting with Homer, Odyssey 11.405-434), which could equally have influenced Antiphon. His use of the name of a character from mythology is exceptional in the orators: all the commentators note the only parallel at And. 1.129. ${ }^{16}$ This may be another sign of the lack of real evidence in the case, with Antiphon relying on the metaphor to kindle in the jurors the male fears of women that are a feature of so many tragedies (joined to the theme of the wicked stepmother). The metaphor helps to draw attention away from the fact that much of the narrative is the pure invention of its narrator (here the imaginary thoughts of the pallake).

(iii) As we noted above, a third striking metaphor, with poetic flavour, ${ }^{17}$ is

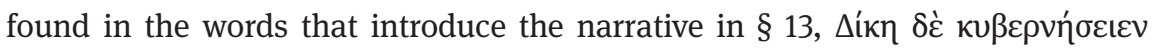

12 Barigazzi 1955, 91.

13 I adopt the text of Gagarin here.

14 Assuming a birth date around 480, with Ps.-Plutarch, Mor. 832F.

15 Gagarin 1997, 116.

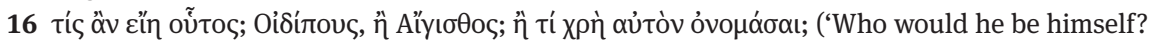
Oedipus or Aegisthus, or what should we call him?').

17 As Gagarin 1997, 27. His other examples of poetic metaphor come from speeches 5 ( $\S \S 37,77$, 93) and 6 (§ 21). More examples of metaphorical expression are given by Cucuel 1886, 28-9:1.13, 17, 20, 2.1.7, 2.2.13, 2.3.10, 4.10, 3.2.10, 3.3.4, 4.2.7 (wrongly given as Гү7 by Cucuel), 5.37, 71, 86, 94. 
('may Justice be my guide'). This metaphor, however, recalls not tragedy, but Pin-

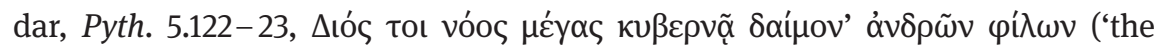
mighty mind of Zeus governs the destiny of men he loves'; cf. Ol. 12.3-5, Pyth. 10.72). Nor is it only poetic: it is also paralleled later in Plato, Euthyd. 291c-d:

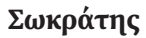

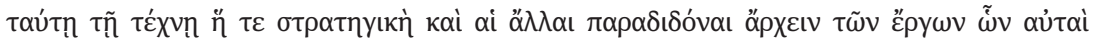

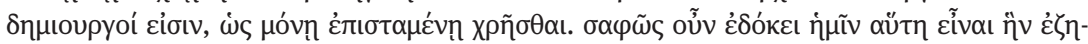

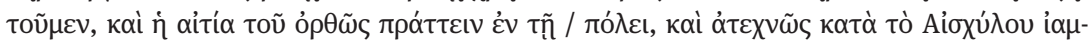

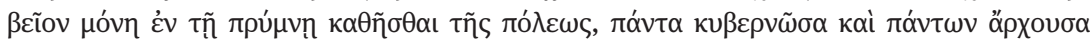

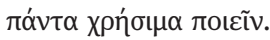

\section{Socrates}

To this art, we thought, generalship and the other arts handed over the management of the productions of their own trades, as this one alone knew how to use them. So it seemed clear to us that this was the one we were seeking, and was the cause of right conduct in the state, and precisely as Aeschylus' line expresses it, is seated alone at the helm of the city, steering the whole, commanding the whole, and making the whole useful. ${ }^{18}$

Socrates refers to the similar metaphor at Aesch. Septem 2, but there the verb

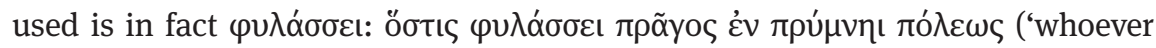
guides affairs at the stern of the state').

(iv) Poetic vocabulary and phraseology make a further contribution to this picture. The first port of call here is the dissertation on Antiphon's language and style by Cucuel, who discusses Expressions poétiques on pp. $22-23 .{ }^{19}$ Cucuel is conservative in his approach, ${ }^{20}$ but he identifies eighteen expressions in the Antiphontean corpus as poetic, two of which are used twice and the great majority of which are found in the Tetralogies. ${ }^{21}$ There are two in speech 1 , both of which

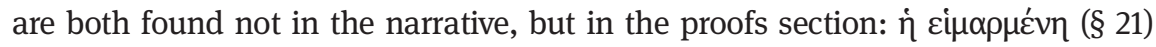
and $\dot{\alpha} \theta \dot{\varepsilon} \mu \iota \tau(\S 22) .{ }^{22}$ It is interesting that the closest parallels for the expression

18 Transl. Lamb 1952.

19 For Cucuel, see n. 17 above.

20 'Mais s'il s'agit de déterminer les expressions poétiques, la tâche devient moins facile' (p. 22).

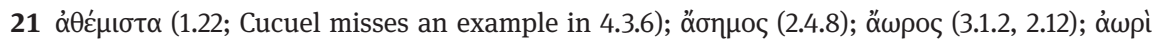

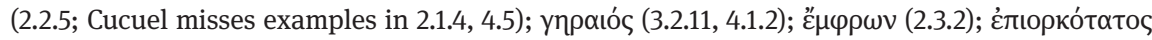

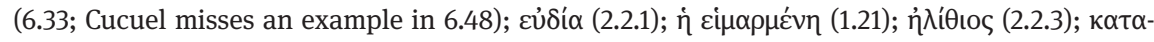

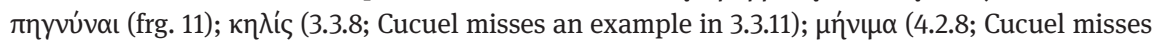

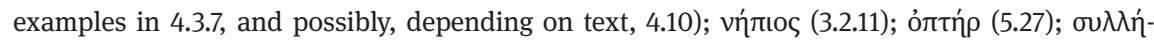

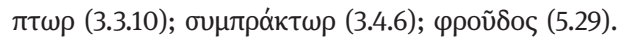

22 Listed by Cucuel as á $\theta \dot{\varepsilon} \mu ı \tau \alpha$, which according to LSJ is the poetical spelling; Gagarin, like Blass/Thalheim in the Teubner, prints $\dot{\alpha} \theta \dot{\varepsilon} \mu \tau \alpha$ at 1.22, but $\alpha \theta \varepsilon \dot{\varepsilon} \mu \sigma \tau \alpha$ at 4.3.6, on which he notes 


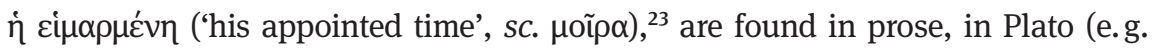
Gorgias 512e) and Demosthenes (e.g. 18.205). Harvey Yunis comments on Dem. 18.195, 'this word is uncommon in Attic oratory (here and §205 out of eight instances); it is so markedly poetic (LSJ s.v. $\left.\mu \varepsilon^{\prime} \rho{ }^{\prime} \mu \alpha \mathrm{III}\right)$ that it lends Athens' fate the feel of tragic necessity'. ${ }^{24}$ More questionably, E. R. Dodds comments on Gorgias 512e, 'in the Homeric sense of the appointed death-day. Though the word is not found as a noun before Plato, it seems to be drawn from the language of poetry'. ${ }^{25}$ But this use in Antiphon is similar to that in Plato. As well as in epic, the expression (though not, I note, precisely the same one) is found in Aeschyl.

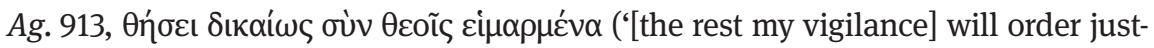

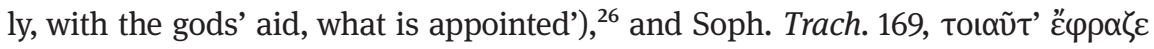

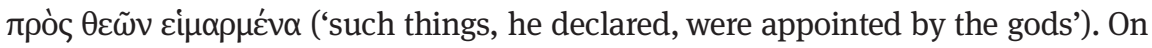
the plot of the Trachiniae, Bruce Heiden writes 'when Deianeira learns that Heracles has brought a young concubine under their roof, she tries to ensure his fidelity by secretly exposing him to a substance she believes has aphrodisiac properties'. ${ }^{27}$ This in many respects makes Deianeira a closer parallel to the stepmother than Clytemnestra, but we cannot draw any inferences over the temporal relationship of the speech with this play as the date of the Trachiniae, as with most of Sophocles' plays, is notoriously difficult to establish. ${ }^{28}$ As for $\dot{\alpha}^{\prime} \varepsilon \dot{\varepsilon} \mu \tau \alpha / \dot{\alpha} \theta \dot{\varepsilon} \mu \mathrm{\tau} \tau \alpha$, this form is not found in Aeschylus or Sophocles, ${ }^{29}$ though

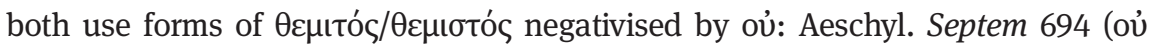

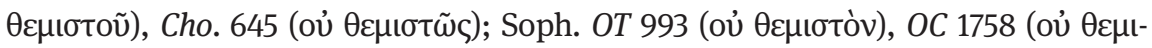

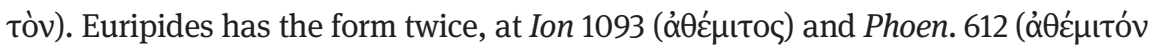

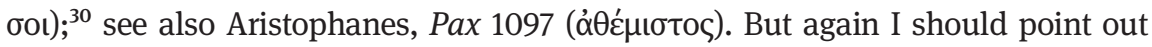
that the parallel uses of the neuter plural are found in prose, both before and after Antiphon (Hdt. 7.33; Xen. Mem. 1.1.9, Cyr. 1.6.6).

$(1997,170)$ that this form 'is fairly common in prose', though a $\theta \varepsilon$ é the fifth and fourth centuries in (the non-Attic) Herodotus $(7.33,8.143)$ and a fragment of Dinarchus quoted in a later source (Bachm. Anecd. 41.1).

23 As Gagarin 1997, 118; Gagarin / MacDowell 1998, 14

24 Yunis 2001, 216.

25 Dodds 1959, 350.

26 Though the text here has been doubted.

27 Heiden 2012, 129.

28 See, e.g., Hoey 1979, 210 - 232, who suggests c. 450. For Easterling, 'any date between 457 and, say, 430 would not be implausible' (Easterling 1982, 23). But other scholars prefer a later date, e. g. Vickers 1995, 41-69 (425/4).

29 The reference to Sophocles in Bachm. Anecd. 41.1 to Sophocles (fr. 742 P) is extremely dubious. See Conomis 1975, 146 (fr. 6 with apparatus).

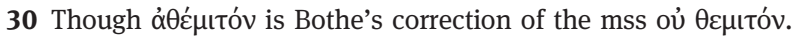


(v) Cucuel goes on to list 'un certain nombre de mots techniques, si l'on peut dire, que l'on désigne souvent sous le nom d'archaïsmes ou de locutions poétiques, paraissent appartenir à un vocabulaire consacré'. ${ }^{31}$ Again, these are mostly found in the Tetralogies, but one occurs in the same passage of the proofs as the

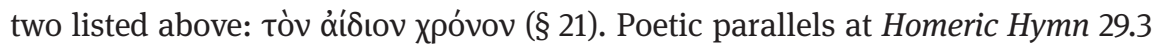
and [Hes.] Scut. 310 are noted by Wijnberg, ${ }^{32}$ but we should also note here Bar-

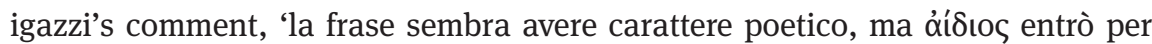
tempo nella prosa ed ebbe lunga vita', with reference to Thuc. 4.63.1. ${ }^{33}$

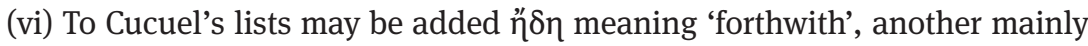
poetic usage which is found in the narrative (§ 20); and oi, the old form of the reflexive pronoun, also found in the speech's narrative ( $\S 16)$. The latter is mostly poetic, but it also occurs at 5.93; Thuc. 2.13.1; And. 1.38. ${ }^{34}$

In addition to vocabulary there are dramatic features in the narrative, which I have discussed elsewhere but may be summarised here. ${ }^{35}$ Most of the sentences are brief, with three or four short cola, which produces a staccato effect. There are, however, some longer cola, which coincide with key points in the narrative,

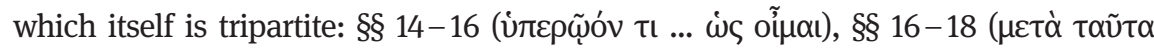

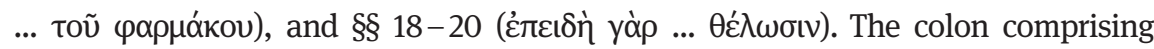
fourteen words in $\S 15$ contributes to the longest sentence in the narrative, where the stepmother tells the pallake that she knows how to restore their respective men's affections. ${ }^{36}$ Another longer colon, of fifteen words this time in $\S 19$, opens the dramatic sentence that vividly narrates how the pallake poured the drink while the two men were offering their prayers - prayers which were never to be answered. ${ }^{37}$ The longest colon, of twenty-two words in $\S 16$, is found towards the start of the second part of the narrative, in a transitional passage where Philoneus has the idea - an 'excellent' one but of course tragically fatal - of accompanying the

31 Cucuel 1886, 23.

32 Wijnberg 1938, 122 n. 5.

33 Barigazzi 1955, 94.

34 Other old-fashioned or rare prose usages in the narrative are the rare use of the aorist infin-

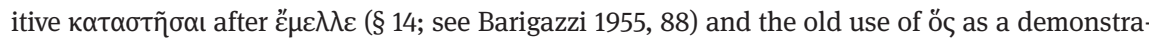

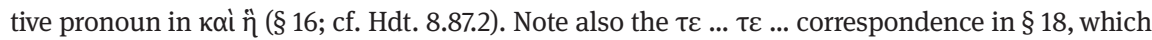
is very frequent in the Tetralogies, but more common in poetry.

35 Edwards 2004, 51-63.

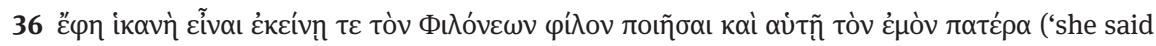
that she was capable of renewing Philoneus' love for her and my father's for herself').

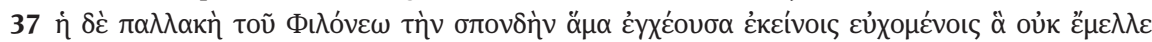
$\tau \varepsilon \lambda \varepsilon \tilde{\sigma} \sigma \alpha \mathrm{s}$ ('Philoneus' mistress, pouring the libation at the same time as they were uttering prayers which were not to be fulfilled'). 
father to Piraeus. ${ }^{38}$ Finally, a colon of seventeen words in $\S 18$ marks the start of the transition to the third part of the narrative, where the narrator becomes overt and prepares the listener/reader for the dramatic scene of the poisoning by skipping over the dinner to the pouring of the fatal libation. ${ }^{39}$

Another feature of the long sentence in $\S 15$ is the use of the vivid historic present tense in $\mu \varepsilon \tau \alpha \pi \dot{\varepsilon} \mu \pi \varepsilon \tau \alpha \mathrm{s}$ and $\dot{\varepsilon} \theta \dot{\varepsilon} \lambda \varepsilon \mathrm{s}$. This use of the present, which recalls the effect of the tense in Euripidean messenger-speeches, ${ }^{40}$ becomes particularly noticeable in the poisoning scene. In $\S 19$ the pallake gives her man more ( $\pi \lambda \lambda^{\prime}$ ov $\delta i \delta \omega \sigma \iota),{ }^{41}$ which of course ironically kills him quicker; and in $\S 20$ the two men,

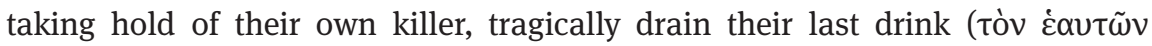

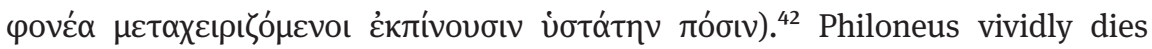

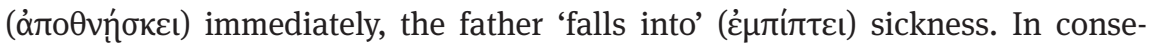

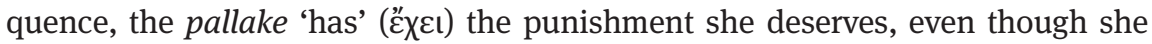

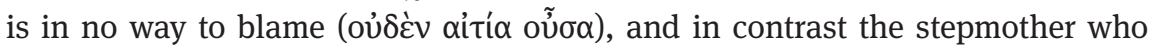
was to blame 'will have' it ( $ع \xi \xi \iota)$.

To conclude, there is no doubt that Antiphon's prosecution of the stepmother as the killer of her husband is reminiscent of a well-known tragic narrative, and the speaker's case relies heavily on that fact. With no real evidence, as far as we can tell, he constructs an at least plausible case against the stepmother that deliberately recalls (but adapts) the situation of Orestes in the Oresteia, and particularly his trial in the Eumenides for avenging the murder of his father by his (in that story natural) mother. ${ }^{43}$ Antiphon will have expected the jurors of the Areopagus to relate to that and indeed question why his client's half-brother was defending this monster, even if she was his mother. The circumstances of the case perhaps made these dramatic

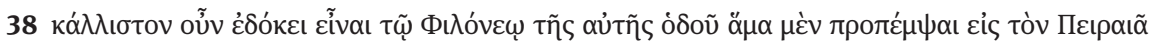

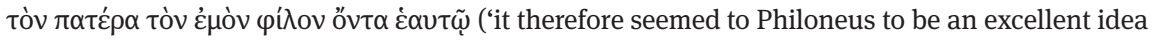

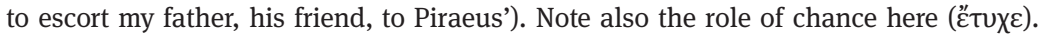

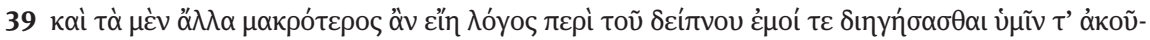
$\sigma \alpha \mathrm{l}$ ('now it would take too long for me to narrate and for you to hear the story of the dinner'). The transition is also marked by the striking verbal periphrasis with an abstract noun in $\dot{\omega} \varsigma$

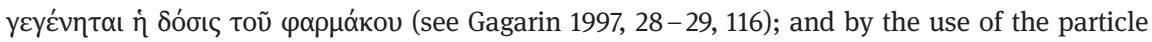
yó $\rho$, which very frequently in the orators indicates the start of the narrative (it is similarly delayed in Lys. 12.4 and 6).

40 As noted by Gagarin 1997, 117, following de Jong 1991, $38-45$.

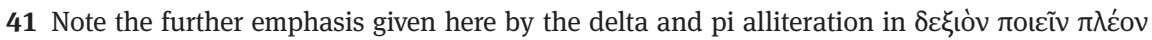
$\delta i \delta \omega \sigma$. Also, the triple use of $\dot{\varepsilon} \gamma \chi \varepsilon \dot{\varepsilon} \omega$; as Gagarin points out $(1997,116)$ the 'use of the same verb for pouring the libation and the poison emphasises the impiety of the crime'.

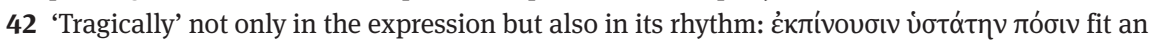
iambic trimeter.

43 The case is evidently weak, but not necessarily hopeless. See, e.g., Gagarin 1997, 106. 
allusions inevitable, but Antiphon makes full use of them, thereby indicating why he was worthy of a place in the canon of ten Attic orators.

\section{Bibliography}

Barigazzi, A. (1955), Antifonte, prima orazione, Florence.

Blass, F. (1887), Die attische Beredsamkeit, vol. 1, Leipzig.

Blass, F. / Thalheim, Th. (1914), Antiphon. Orationes et fragmenta, Leipzig.

Conomis, N.C. (1975), Dinarchi orationes cum fragmentis, Leipzig.

Cucuel, C. (1886), Essai sur la langue et le style de l'orateur Antiphon, Paris.

Dodds, E.R. (1959), Plato: Gorgias, Oxford.

Dover, K.J. (1950), 'The Chronology of Antiphon's Speeches', in: CQ 44, 44-60.

Due, B. (1980), Antiphon: A Study in Argumentation, Copenhagen.

Easterling, P.E. (1982), Sophocles: Trachiniae, Cambridge.

Edwards, M.J. (2000), 'Antiphon and the Beginnings of Athenian Literary Oratory', in: Rhetorica 18, $227-42$.

- (2004), 'Narrative levels in Antiphon 1, Against the Stepmother', in: A. López Eire / A. Ramos Guerreira (eds.), Registros Linguísticos en las lenguas clásicas, Salamanca, $51-63$.

Gagarin, M. (1997), Antiphon: The Speeches, Cambridge.

- (2002), Antiphon the Athenian: Oratory, Law, and Justice in the Age of the Sophists, Austin.

Gagarin, M. / MacDowell, D.M. (1998), Antiphon and Andocides, Austin.

Gernet, L. (1923), Antiphon. Discours, Paris.

Heiden, B. (2012), 'Trachiniae', in: A. Markantonatos (ed.), Brill's Companion to Sophocles, Leiden, $129-48$.

Hoey, T.F. (1979), 'The Date of the Trachiniae', in: Phoenix 33, 210-32.

Jebb, R.C. (1893), The Attic Orators from Antiphon to Isaeus, vol. 1, London.

Jong, I.J.F. de. (1991), Narrative in Drama: The Art of the Euripidean Messenger-Speech, Leiden.

Lamb, W.R.M. (trans.) (1952), Plato vol. IV, Cambridge, Mass. / London.

Lloyd, M. (1992), The Agon in Euripides, Oxford.

- (2013), Review of Sansone (2012), in: CJ 108, 457-459.

Maidment, K.J. (1941), Minor Attic Orators I: Antiphon, Andocides, Cambridge, MA.

Sansone, D. (2012), Greek Drama and the Invention of Rhetoric, Chichester / West Sussex / Malden, MA.

Scodel, R. (2013), Review of Sansone (2012), in: BMCR 2013.06.16.

Stewart, E. (2014), Review of Sansone (2012), in: CR 64.1, 26-28.

Vickers, M. (1955), 'Heracles Lacedaemonius: the political dimension of Sophocles Trachiniae and Euripides Heracles', in: Dialogues d'histoire ancienne 21, 41-69.

Wijnberg, S. (1938), Antiphon's Eerste Rede, Amsterdam.

Xanthakis-Karamanos, G. (1979), 'The Influence of Rhetoric on Fourth-Century Tragedy', in: CQ $29,66-76$.

Yunis, H. (2001), Demosthenes: On the Crown, Cambridge. 